• 论坛・

\title{
我国自然保护地历史遗留问题的系统解决方案
}

\author{
黄宝荣 ${ }^{1} \quad$ 张丛林 ${ }^{1}$ 邓 舟 $^{2 *}$ \\ 1 (中国科学院科技战略咨询研究院, 北京 100190) \\ 2 (成都理工大学地球科学学院, 成都 610059)
}

\begin{abstract}
摘要: 近年来, 我国自然保护地内存在的大量的人口密集区域、民生设施、矿业活动、开发建设项目、农牧业生 产活动等历史遗留问题在中央环保督察中集中暴露出来。为采取针对性政策措施解决这些遗留问题, 本研究首先 将其分为三大类: (1)保护越位与保护空缺并存; (2)生态保护和大量原住居民生计改善间的矛盾突出; (3)保护地内 存在大量生产经营活动。在此基础上，深入剖析了各类遗留问题产生的体制机制原因。为合理化解历史遗留问题 导致的一系列矛盾, 提高保护地建设和管理质量, 本文从加强保护地体系的顶层设计、推动相关法律法规的制修 订、采取多元化手段解决保护地内土地权属和矿业权问题、建立健全平衡保护与发展关系的体制机制等 4 个方面 提出了历史遗留问题的系统性解决方案。
\end{abstract}

关键词: 自然保护地; 历史遗留问题; 产生原因; 系统性解决方案

\section{The systemic solution to historical problems in China's natural protected areas}

Baorong Huang ${ }^{1}$, Conglin Zhang ${ }^{1}$, Ran Deng ${ }^{2 *}$

1 Institutes of Science and Development, Chinese Academy of Sciences, Beijng 100190

2 College of Earth Sciences, Chengdu University of Technology, Chengdu 610059

\begin{abstract}
Recently, the Chinese central government identified key problems in their history that has resulted in poor care for naturally protected areas. Some examples of these problems include having densely populated areas, community livelihood facilities, mining activity, and construction projects occurring in these naturally protected areas. In an attempt at finding solutions to these problems, we first classify these problems into three major categories: (1) both of overprotection and protection gap is existing; (2) conflict between conservation efforts and improving the livelihood of residents living near or in protected areas; (3) a great deal of business activity in protected areas. This study then describes an in-depth analysis on the institutional reasons for each category of historical problems. Finally, in order to rationally resolve these problems and improve the quality of protected area construction and management this study proposes the following systematic solutions from four aspects: (1) strengthening the top-level design of planning and construction of China's protected areas; (2) formulating and revising relevant laws and regulations for protected areas; (3) taking measures to resolve problems dealing with land tenure and mining rights in protected areas; (4) establishing institutional mechanisms to balance both conservation and development of protected areas.
\end{abstract}

Key words: natural protected area; problems left over by history; institutional reason; system solution

我国自然保护地始建于1956年, 在此后40多年 里, 其数量和面积均稳步增长。1998年全国特大洪 港灾害进一步坚定了我国加大生态环境保护力度
的决心, 保护地的建设速度进一步加快。截至2018 年, 我国已建成包括自然保护区、风景名胜区、森 林公园、湿地公园等在内的各类保护地 1.18 万处,

收稿日期: 2020-08-07; 接受日期: 2020-10-15

基金项目: 第二次青藏高原综合科学考察研究(2019QZKK0401)和2018年度教育部哲学社会科学研究重大课题攻关项目(18JZD059)

* 通讯作者 Author for correspondence. E-mail: 1173793435@qq.com 
各类陆域保护地总面积占陆地国土面积的 $18 \%$ 以上 (高吉喜等, 2019)。这些保护地在保护我国重要生态 系统和生物多样性中发挥了重要作用。

但长期以来，我国保护地实行的基本是“抢救 式保护”策略, 缺乏顶层设计和整体规划, 注重数 量和面积的扩张, 忽视管理质量和能力的提升。特 别是近年来, 随着中央环保督察、“绿盾”自然保护 区监督检查专项行动和“绿剑”专项打击行动的开展, 保护地内的历史遗留问题集中暴露出来, 如存在大 量的人口聚集区、开发建设项目、农牧业生产活动 等。这些历史遗留问题一方面是我国保护地建设管 理中的重要制约因素; 另一方面成为影响社会稳定 的潜在因素, 一些保护地生态保护和社会经济发展 的矛盾十分尖锐。

当前, 我国正在推动以国家公园为主体的自然 保护地体系建设。2019年6月, 中共中央办公厅、国 务院办公厅印发了《关于建立以国家公园为主体的 自然保护地体系的指导意见》, 其中第十六条为分 类有序解决保护地历史遗留问题指明了方向，但仍 缺乏具体可操作的细化方案。在此背景下, 深入剖 析历史遗留问题产生的原因, 提出系统性的解决方 案, 对于科学有序地化解这些遗留问题, 将我国保 护地建设好、管理好具有重要意义。

\section{国内外自然保护地历史遗留问题研究现垙}

发达国家建立自然保护地的时间较早, 其历史 遗留问题主要体现在保护地内的私有土地和原住 居民等方面。对于私有土地，一方面通过赎买、置 换等方式, 将土地所有权集中到保护地管理机构, 从而实现土地的统一管理 (Grazia et al, 2013; Worboys et al, 2015); 另一方面通过与土地所有者 签订协议, 以地役权限制其土地利用方式, 并鼓励 土地所有者参与到保护地管理中 (Jacobs，2014; Korngold, 2010)。对于原住居民问题, 则通过立法规 定原住居民参与保护地管理的权利和义务, 如加拿 大通过《宪法法案》确定印第安人对保护地内部分 土地可以行使的权利, 并由保护地管理机构与原住 居民签订社区共管协议(蓝楠和包旭, 2019)。

相比发达国家，我国保护地建设起步较晚，人 口众多、经济社会发展滞后、区域发展不平衡等原 因使我国保护地所面临的历史遗留问题更严峻。已
有研究认为我国保护地存在的主要历史遗留问题 包括: 保护地内存在大量的人口、种植和养殖活动、 矿业权、水利水电设施等(王智等, 2008; 徐网谷等, 2016; 张博和利广杰，2017)。这些问题产生的原因 主要为: 管理体制不完善、相关法律法规缺失、保 护地管理机构不享有土地所有权和使用权等(欧阳 志云等，2002; 王灿发，2006; 周建华和温亚利, 2006; 夏欣等, 2016)。已有研究从加强法律保障、 完善管理体制、倡导社区共管、建立生态补偿制度、 加强资金保障、重视并引入管理人才等方面提出对 策建议(马燕, 2006; 肖建华和周训芳, 2009; 陈红梅 和王智, 2011; 钱者东等, 2016)。在实践层面, 有关 部门积极探索，出台了相关政策(Box 1)。

但总体而言，如何科学系统地解决历史遗留问 题, 还需要进一步深入研究。限于国情和发展阶段 的差异, 国外相关经验难以直接借鉴。而国内学术 和实践层面所提出的解决方案，一方面对历史遗留 问题产生的深层次原因剖析尚有不足，难以从根源 上精准施策; 另一方面多从某一部门、某一角度提 出解决方案, 缺乏统筹, 难以系统性解决这些问题。

\section{自然保护地历史遗留问题及其产生原因}

《关于建立以国家公园为主体的自然保护地 体系的指导意见》中指出，我国自然保护地的历史 遗留问题主要包括: 保护地范围内包含大量保护价 值低的建制城镇、村屯或人口密集区域、社区民生 设施; 大量原住居民; 大量探矿采矿、水电开发、 工业建设等项目; 大量耕地及农业生产活动等。根 据其造成的负面影响和产生的体制机制原因，可以 将其进一步归为具有一定因果关系的三大类: 保护 越位与保护空缺并存; 生态保护和大量原住居民生 计改善间的矛盾突出; 保护地内存在大量生产经营 活动。

\section{1 保护越位与保护空缺并存 \\ 2.1.1 问题分析}

一方面，长期以来我国实行“抢救性保护”策略, 许多保护地在划定时将大量生态保护价值低的区 域，如建制城镇、村屯、耕地、民生设施等划入保 护范围，造成保护越位。据统计，在我国474个国家 级自然保护区内，分布有29个城市建成区、531个建 制乡镇建成区、 5,779 个行政村、 374 万人口 (https://www.cenews.com.cn/opinion/201907/t201907 


\section{Box 1 解决自然保护地历史遗留问题的相关政策文件}

(1) 2013年12月，国务院发布《国家级自然保护区调整管理规定》，相关内容: 在批准建立之前区内存在建制镇或城市 主城区等人口密集区，且不具备保护价值的自然保护区，可申请对自然保护区进行调整。

(2) 2015年5月，原环境保护部等十部门发布《关于进一步加强涉及自然保护区开发建设活动监督管理的通知》，相关 内容: 对自然保护区设立之前已存在的合法矿业权，以及自然保护区设立之后各项手续完备且已征得保护区主管部门同 意设立矿业权, 要分类提出差别化的补偿和退出方案，在保障矿业权人合法权益的前提下，依法退出自然保护区核心区和 缓冲区。

（3）2017年7月，原国土资源部发布《自然保护区内矿业权清理工作方案》，相关内容: 对保护区内的矿业权进行全面 调查摸底、分类梳理、系统分析，做好矿业权分类处置、稳妥有序退出保护区基础工作，并确保新设矿业权不再进入自然 保护区。

（4）2018年3月，原国土资源部发布《关于全面实行永久基本农田特殊保护的通知》，相关内容: 位于国家自然保护区 核心区内的永久基本农田，经论证确定可逐步退出，按照永久基本农田划定规定，原则上在该县域内补划。

(5) 2019年6月，中共中央办公厅、国务院办公厅发布《关于建立以国家公园为主体的自然保护地体系的指导意见》，相 关内容: (1)科学评估, 合理调整保护区范围, 原住居民应实施有序搬迁; (2)分类处置, 有序退出探矿采矿、水电开发、工业 建设等项目; (3)依法界定各类自然资源资产产权主体的权利和义务，保护原住居民权益。

(6) 2019年7月, 自然资源部、财政部、生态环境部、水利部、国家林业和草原局发布《自然资源统一确权登记暂行办 法》，相关内容: (1)国家批准各类自然保护地应当优先作为独立登记单元划定; (2)明确自然保护区、自然公园等自然保护 地范围内各类自然资源的数量、质量、种类、分布等自然状况, 及所有权主体、所有权代表行使主体、所有权代理行使主 体以及权利内容等权属状况。

15_902180.html.2019-07-15)。省级以下自然保护区 更是如此(向玉国等, 2019), 如山西汾河上游省级自 然保护区在农民完全不知情的情况下, 将7个乡镇 71个行政村划入到保护区(王跃文, 2019)。保护越位 不仅造成保护地管理的困难，激化保护和发展间的 尖锐矛盾，也导致大量保护资金投入到保护价值较 低的区域，造成资金浪费。

另一方面, 我国还有大量具有重要保护价值的 区域未纳入保护地体系, 造成保护空缺。据研究, 我国现有保护地体系只覆盖了已识别的生物多样 性关键区总面积的 $48.1 \%$ 和生物多样性保护优先区 的 23.1\%; 各级陆地自然保护区仅分别覆盖了 $13.1 \% 、 17.9 \% 、 16.4 \% 、 10.0 \%$ 和 $8.4 \%$ 的植物、哺乳 动物、鸟类、两栖动物和爬行动物生境 $(\mathrm{Xu}$ et $\mathrm{al}$, 2017); 截至2014年, 我国仍有约1,744种脊椎动物 受到较少或未受就地保护(周大庆等, 2016)。海洋 类 型保护地面积仅占我国管辖海域面积的 4\%左右, 与保护目标仍有明显差距。

\subsection{2 问题产生的制度和政策原因}

保护地保护越位和空缺并存, 既有国家层面体 制和政策方面的原因, 也有地方政府发展思路和政 策执行方面的原因。

(1)国家层面体制和政策方面。在体制方面, 长
期以来，我国保护地管理职能分散在不同部门，使 保护地体系缺乏科学系统的顶层设计和整体规划, 缺乏各类保护地建设的远景目标和路径，各部门根 据不同保护目的分别规划、设置各类保护地，造成 保护地交叉、重叠的同时，难免造成大量保护空缺。 在政策方面，由于要实施抢救性保护，不少保护地 在划定之初带有强制色彩，要在较短时间内完成基 础资料的调查和勘察定界工作; 一些保护地在未进 行科学考察的情况下匀忙设立, 甚至在地图上直接 圈画确定。在技术层面，很长一段时间内缺乏具体 可操作的保护地划定标准与指南，使保护地划定依 据不足; 早期勘查测绘技术也比较落后, 客观上造 成了保护地范围划分不精确。

(2)地方政府保护地建设思路和政策执行方面。 在建设思路上，一些地方政府对保护地建设的目的 理解不到位，导致保护地划定出现偏差。如自然保 护区建立的主要目的是保护珍稀濒危野生动植物 物种分布区和具有代表性的生态系统，而地方政府 却将大量低保护价值区划入。在政策执行方面，一 些地方政府为了争取更多的中央或省级财政转移 支付, 尽可能划大保护地 (http://www.iziran.net/ pinglun/20190813_120788.shtml), 导致很多低生态 保护价值区域被划入; 一些地方政府在设立保护地 
时没有与农业、国土等部门沟通衔接, 造成划定的 范围与农村居民点、基本农田和矿业权等交叉重叠 (罗怀斌和蒙涁, 2014)。

\section{2 生态保护和大量原住居民生计改善间的矛盾} 突出

\subsection{1 问题分析}

我国各类保护地内及其周边居住着大量的原 住居民。截至2014年底, 全国已明确边界的1,657个 自然保护区内, 分布有 1,256 万人口(徐网谷等, 2016); 10 个国家公园体制试点范围内分布有 60 余万 原住居民(十个国家公园体制试点方案, 部分未公 开); 一些森林公园和风景名胜区内也分布众多原 住居民(王淑芳，2010；宋志伟，2018)。各类保护地 周边更是分布着数量众多的以保护地自然资源为 重要生计来源的社区和居民(孙润等, 2017; 王会等, 2017; 刘奕汝和许碧果, 2019)。以孟津黄河湿地国 家级自然保护区为例，其周边分布有包括近 10 万人 口的农村社区，大量居民以保护区内的耕地和鱼塘 作为主要生计来源。保护地保护和原住居民生计改 善之间的矛盾突出, 并造成社区贫困问题(刘霞等, 2011; 王昌海, 2017; Ma et al, 2019; Zhang et al, 2020)。我国 592个国家级贫困县中, 99\%都在距离保 护区100 km范围内。大量居住在保护区内和周边的 农户，其家庭收入和生活水平均低于贫困线(马奔 等, 2017)。

\subsection{2 问题产生的制度和政策原因}

造成保护地及周边生活着大量原住居民的主 要原因, 除了我国人口众多、保护地广泛分布于地 处偏远的自然区域的客观事实外, 还有社会经济和 体制机制层面的原因。

(1)社会经济与政策环境不利于原住居民迁出。 一是城乡二元结构、区域发展不平衡、不充分。一 方面, 保护地及周边往往教育资源短缺, 原住居民 受教育程度低, 生计资本和非农就业技能缺乏, 难 以摆脱对保护地自然资源的生计依赖(段伟等, 2015; 王会等, 2017); 另一方面, 保护地往往地处偏远, 所在县域社会经济发展水平低, 非农就业机会少, 原住居民在县域内实现就地城镇化难度大。二是生 态移民政策的推动实施面临很大困难。当前我国生 态移民的配套政策如生态补偿、产业扶持、文化传 承、职业技能培训、教育保障等尚不健全，造成原 住居民对移民政策心存后顾之忧，政策实施难度大，
一些保护地甚至出现移民回迁的现象(谭伟福等, 2016)。

(2)缺乏具体的利益相关方参与制度。我国保护 地的利益相关方参与制度十分薄弱，已有制度中关 于利益相关方参与的条款基本上是原则性的，缺乏 具体的制度安排。保护地主要由地方政府管理, 较 少吸纳社区居民的意见，极易造成与原住居民间的 矛盾和隔阂。尽管一些保护地探索了社区共管制度 并取得了一些成效，但仍面临法律和资金保障不足 的问题, 并未在全国范围内推行。近年来, 我国社 会公益组织投入保护地生态保护的意愿强烈，但由 于缺乏法律授权, 工作推动难度较大。

(3)生态产品价值实现机制不健全。一是当前针 对保护地的生态补偿机制不健全。我国针对保护地 的生态补偿资金依然不足，原住居民受到的损失没 有得到合理补偿, 特别是保护地周边在保护地内没 有自然资源所有权或承包经营权而发展机会受限 的原住居民, 更难以获得补偿。二是保护地特许经 营制度不健全。我国风景名胜区和国家公园体制试 点区开展了一些特许经营制度的探索，但无论是特 许程序的规范性还是利益分配机制均存在较多问 题(张晓, 2012)。保护地的旅游、商业经营活动长期 由当地政府或外来投资者主导，作为产权所有者的 原住居民获益较少(李文军和马学蓉, 2009; 赵刚等, 2013)。三是生态产品实现的市场机制不健全。保护 地重点生产生态产品，但由于自然资源产权制度、 生态产品价格机制和市场交易机制不健全，好的产 品没有卖出好的价钱，绿水青山的守护者没有收获 金山银山。

\section{3 保护地内存在大量生产经营活动 \\ 2.3.1 问题分析}

我国保护地存在大量的耕种、放牧、水电开发、 矿产资源开发、采石采砂等生产经营性活动, 对保 护地生态环境造成了严重破坏(徐网谷等, 2016; 张 博和利广杰, 2017; 曹巍等, 2019; 孟宝等, 2019)。这 些生产经营性活动在历次中央环保督察和“绿盾”、 “绿剑”专项行动中暴露出来：如2017年中央督察组 发现祁连山国家级自然保护区存在大量违法违规 开发矿产资源、兴建水电设施的现象; 内蒙古兴安 盟图牧吉国家级自然保护区内有大量常年性的耕 种、放牧、捕捞等生产经营性活动, 违规面积达保 护区总面积的 $95 \%$ 以上; 湖南大义山省级自然保护 
区内违规设置探矿、采矿权, 且试图通过调整保护 区范围替代矿山清理等。

\subsection{2 问题产生的制度和政策原因}

各类生产经营活动在保护地内大量存在且难 以根除，主要有两方面原因。

(1)保护地的法律位阶低、法律保障与授权不 足。长期以来, 我国保护地主要依据《自然保护区 条例》和《风景名胜区条例》两个国务院条例进行 管理, 法律位阶低, 当与其他位阶更高的法律发生 冲突时, 难以依法对保护地内的生产经营性活动进 行处理。同时，未对保护地历史遗留问题的解决原 则和方式等作出明确规定。对保护地管理机构的行 政执法授权也不足, 造成执法困难。此外, 保护地 自然资源产权、国土空间用途管制等制度未纳入 《物权法》《不动产登记条例》《土地管理法》等相 关法律法规，使保护地管理机构在处理历史遗留的 土地权属问题时缺乏法律依据。以《自然保护区条 例》为例, 未对如何处理保护区内历史遗留的土地 权属问题作出明确规定, 土地权属长期按照《土地 管理法》和《自然保护区土地管理办法》中的相关 规定执行。特别是《自然保护区土地管理办法》规 定“依法确定的土地所有权和使用权, 不因自然保 护区的划定而改变”, 造成保护区管理机构无法获 取集体土地使用权而使用途管制缺乏合法性。

(2)土地权属混乱, 保护地管理机构难以获取 土地管理权。我国保护地管理普遍面临土地所有 权、使用权、经营权、管理权归属不清的制约。一 是保护地内存在众多全民所有和集体所有之间、不 同集体所有者之间边界不清的问题。二是一些地区 地籍管理混乱, 很多国有土地没有经过合法的土地 承包经营程序而被村集体或个人使用。以吉林向海 国家级自然保护区为例, 农户在保护区内的耕地除 了法律认可的口粮地、机动地外, 还有大量缺乏法 律授权但被村集体认可的“手指地”; 土地承包经营 权流转常以口头协议的形式进行, 没有正式合同, 甚至出现同一块土地多次流转或同时流转给多人 的现象。三是地方政府和多个部门依据不同的法规 均对保护地内所有或部分土地拥有管理权限, 如农 业部门对耕地、水利部门对河道等有一定的管理权 限。复杂的土地权属问题给保护地管理机构通过征 收、流转等途径获取土地使用权和管理权带来巨大 困难。
很多保护地在划定之初土地大多已划归集体, 国有土地也被大量承包经营。在我国经济下行压力 加大的背景下, 完全依赖财政资金征收、流转这些 土地面临很大困难。以国家公园体制试点区为例, 大熊猫、武夷山和南山 3 个试点区内分别分布有约 6,754、701、372 $\mathrm{km}^{2}$ 的集体土地，一次性征收或流 转这些集体土地几无可能。以河南孟津黄河湿地国 家级自然保护区为例，截至2017年，该保护区核心 区和缓冲区内共有耕地70,170亩、鱼塘8,609亩。这 些耕地是周边社区集体所有，也是社区居民的基础 生计来源，如果参照类似区域实施的550-1,200元/ 亩/年的补偿标准对其进行流转, 则每年需要的补 偿金额高达2,500-5,400万元; 渔业是当地经济发展 的重要支柱和一些农户的主要收入来源, 若全面清 理鱼塘，也需支付高额的补偿资金。若没有中央财 政的支持，地方政府将面临巨大的财政和民生压力。

同时，我国各类保护地内分布着大量的矿业 权。仅国家级自然保护区内就有探矿权 1,855 个, 重 叠面积约 69,107 $\mathrm{km}^{2}$; 采矿权 782 个, 重叠面积 $2,421 \mathrm{~km}^{2}$, 矿产资源开发与自然保护区管理冲突明 显。很多矿业权是在保护地划定之前取得，一些在 保护地划定之后取得的矿业权在程序上也具有合 法性, 处置难度较大。

\section{系统性解决方案}

保护地历史遗留问题涉及范围广、主体多、层 次深，造成问题的原因是系统性和体制机制性的， 单一的政策措施难以从根源上彻底解决这些问题。 因此，需根据问题产生的深层次体制机制原因，加 强顶层设计, 从战略规划、法律保障、体制建设、 政策优化等全方位构建一个相互统筹协调的系统 性解决方案(图1)。

\section{1 加强保护地体系规划建设的顶层设计}

\subsection{1 制定我国自然保护地建设的中长期战略}

加强保护地体系顶层设计的首要任务是制定 保护地建设的中长期战略, 明确到2035和2050年与 我国社会主义现代化强国建设相适应的各类保护 地建设远景目标，以提前做好部署，逐步有序地提 高我国保护地面积比例，避免“抢救式保护”造成的 低质量发展。在中长期规划编制之前, 需要加强保 护地建设远景目标的前瞻研究，明确不同阶段需要 划定的最小的陆域和海洋保护地面积比例。2009年, 


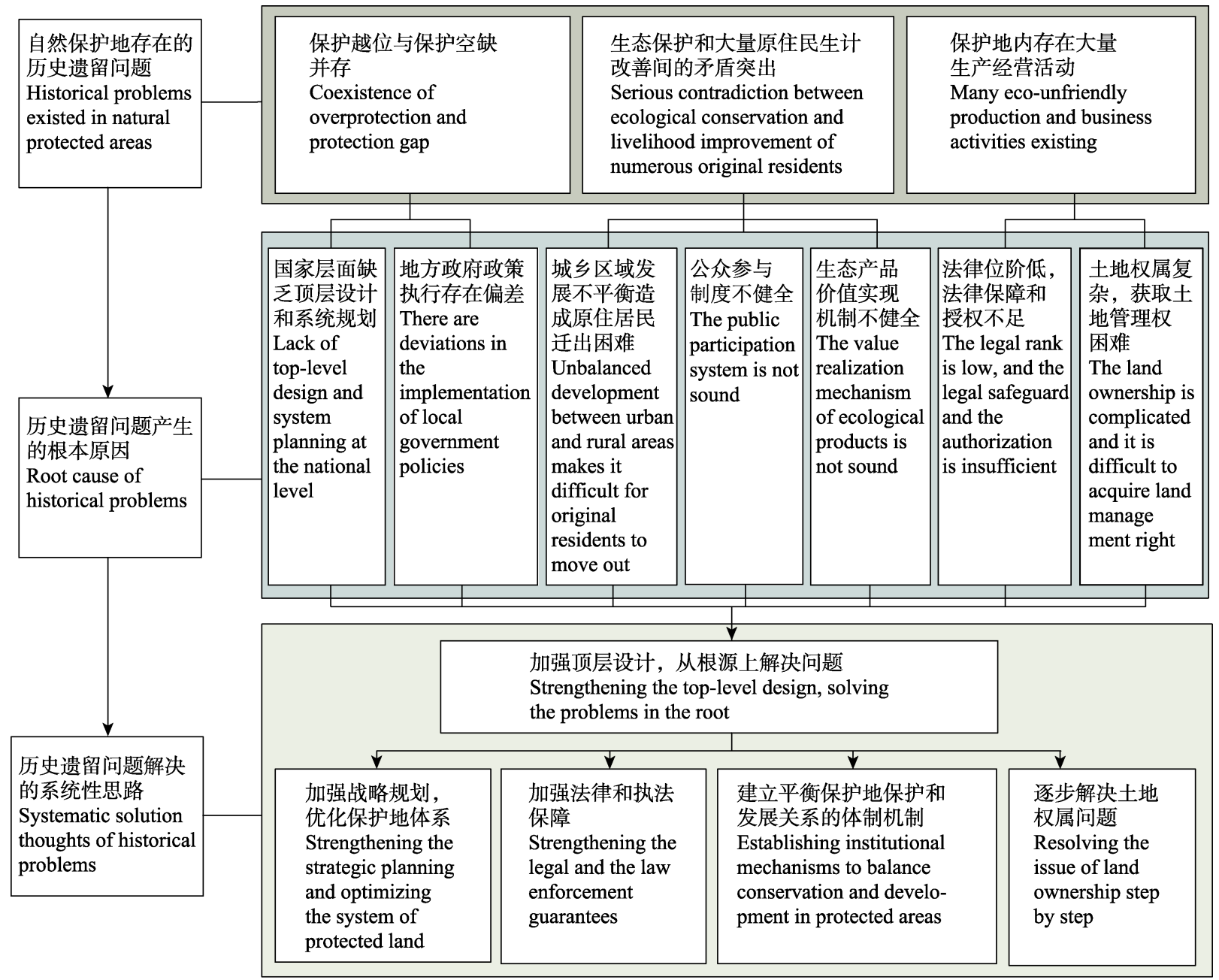

图1 我国自然保护地历史遗留问题剖析及系统性解决方案

Fig. 1 Analysis and the systematic solution of the historical problems in China's natural protected areas

荒野基金会(WILD Foundation)发起了“自然需要一 半”倡议, 提出应该将地球至少 $50 \%$ 的陆地和 $50 \%$ 的 海洋区域作为某种形式的保护地(曹越等, 2019)。近 年来, 这一倡议开始进入全球环境政策的主流讨论 之中。我国作为生物多样性最丰富和受威胁最严重 的国家之一, 需加快部署相关研究, 以免未来在相 关国际公约签订和履行中处于被动地位。

\subsection{2 推动保护地体系的优化重组}

新建一批保护地, 填补主要保护空缺。尽快启 动全国重要自然生态系统、重要野生动植物栖息地 和迁徙廊道、重要自然遗迹和自然景观的调查评估, 识别保护空缺, 通过新建一批保护地或就近纳入现 有保护地，填补主要保护空缺。结合国土空间规划 编制, 衔接生态保护红线的划定、调整; 根据生态 重要性，协调推进新建保护地和永久基本农田核实 整改工作，避免交叉重叠。
启动一批保护地的范围和功能区调整。首先, 制订历史遗留问题认定技术规范，避免以解决历史 遗留问题的名义而压缩保护空间。其次，根据生态 系统完整性和原真性保护要求, 将与现有保护地生 态系统过程联系紧密、保护价值较高的区域纳入保 护范围; 将保护价值较低的建制镇、村屯等人口密 集区域调整出保护范围。再者，结合自然保护区三 区变两区调整工作，将保存完好的天然状态的生态 系统，珍稀、濒危动植物的集中分布地，珍稀、濒 危动物可能活动的区域调整到核心保护区，禁止人 为活动; 将受到一定人类活动干扰，但基本实现人 地协调、相对维持较好的生态状态的区域调整到一 般控制区，限制人类活动，维持自然教育、科研、 游頽等功能。

\section{2 推动相关法律法规的制定和修订}

在正在推动的《自然保护地法》和《国家公园 
法》的立法中, 建议增加保护地历史遗留问题的界 定和处理原则条款，并在下位法如《自然保护区条 例》今后的修订中细化相应条款, 明确各类历史遗 留问题的具体解决方式。加强法律之间的协调性, 如分别在《自然保护地法》《土地管理法》《基本农 田保护条例》中明确保护地内各类土地权属的规定, 并保持协调一致。推动《物权法》《不动产登记条 例》等已有相关法律法规的修订, 增加关于保护地 内自然资源产权、国土空间用途管制等问题的条款。

推进保护地执法改革, 建立以保护地管理机构 为主、相关部门参与的统一执法机制, 在保护地范 围内实行资源环境综合执法。在相关法律法规中明 确违法犯罪行为, 提高相应的处罚标准, 并视情况 追究民事或刑事责任。严格执法监督，加强行政执 法与刑事司法的衔接, 授权检察院对保护地内的资 源环境综合执法司法活动开展法律监督。

\section{3 采取多元化手段解决保护地内土地权属和矿 业权问题}

\subsection{1 推动保护地自然资源资产确权登记}

根据《自然资源统一确权登记暂行办法》，优 先启动各类保护地内的土地、水流、森林、山岭、
草原、荒地、滩涂等所有自然生态空间的统一确权 登记，明确保护地范围内各类自然资源的数量、质 量、种类、分布等自然状况，及所有权主体、所有 权代表行使主体、所有权代理行使主体以及权利内 容等权属状况，建立权责明确的自然资源产权体系， 解决土地及附着于土地的各类自然资源权属争议 问题。

\subsection{2 依法有序解决土地权属问题}

保护地内土地权属问题要依法有序解决。对于 非法侵占使用保护地土地的生产经营性行为一律 依法清退。对于当前依法拥有的保护地土地所有 权、承包经营权或管理权，根据保护地的类别、级 别和功能分区，因地制宜采取多元化措施解决其土 地权属问题(表1)。如国家公园保护我国最具生态重 要性、代表性的自然资源, 为了确保对这些自然资 源的严格保护，并根据《建立国家公园体制总体方 案》中提出的“确保全民所有的自然资源资产占主 体地位”，建议尽可能逐步通过征收、置换、赎买等 收回核心保护区所有土地的所有权、使用权和管理 权。一方面, 从必要性来看, 可避免未来权属问题 制约核心保护区最重要生态系统的严格保护; 另一

表1 我国自然保护地土地权属问题的分区分类解决方案

Table 1 Zoning and classification solutions for the problems of land ownership in China's natural protected areas

\begin{tabular}{|c|c|}
\hline $\begin{array}{l}\text { 权属类型 } \\
\text { Types of land ownership }\end{array}$ & 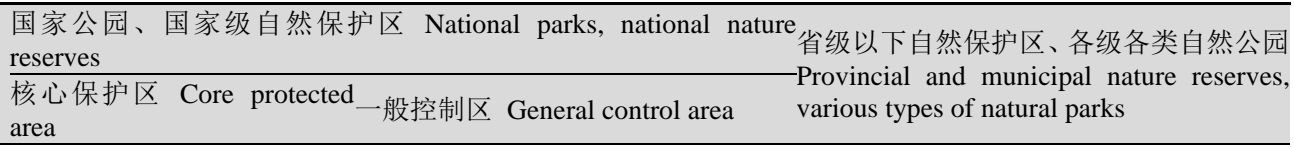 \\
\hline $\begin{array}{l}\text { 全民所有(未被承包经营, 但管理 } \\
\text { 权归属于其他部门) } \\
\text { Ownership by the whole people (it } \\
\text { is not contracted for operation, but } \\
\text { the management right belongs to } \\
\text { other departments) }\end{array}$ & 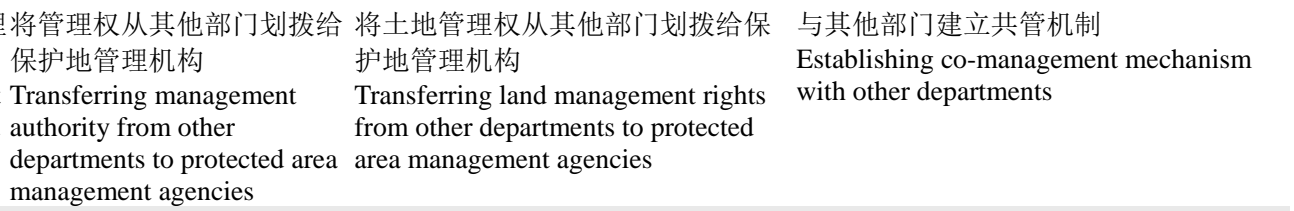 \\
\hline $\begin{array}{l}\text { 全民所有(被单位或者个人承包 } \\
\text { 经营) } \\
\text { Ownership by the whole people } \\
\text { (contracted for operation by units } \\
\text { or individuals) }\end{array}$ & 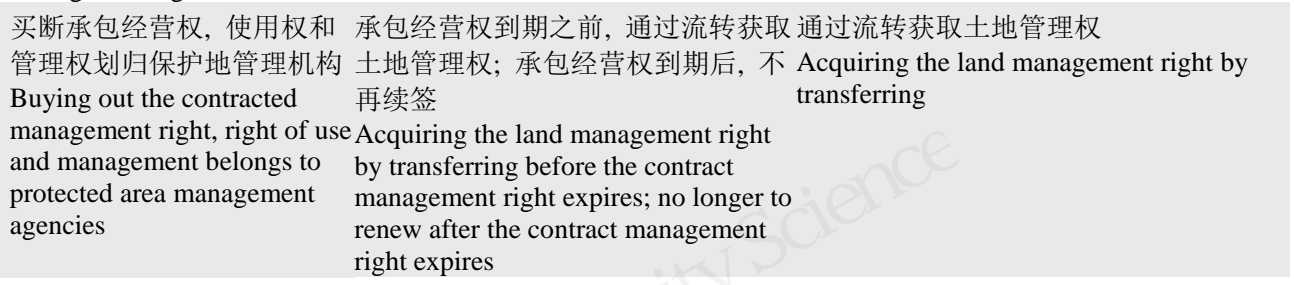 \\
\hline $\begin{array}{l}\text { 集体所有 } \\
\text { Collective ownership }\end{array}$ & 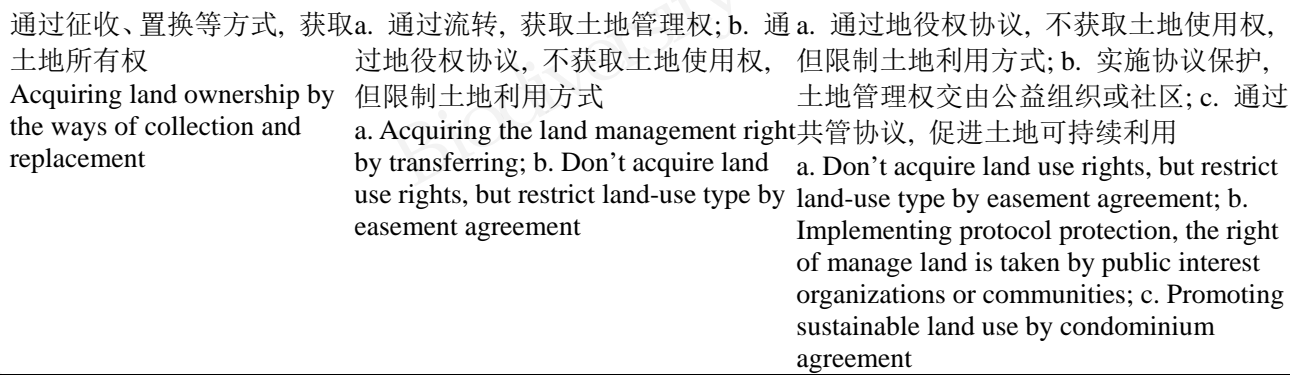 \\
\hline
\end{tabular}


方面，从可行性来看，划为国家公园核心保护区的 区域一般自然生态系统的比例高, 集体土地和承包 经营的国有土地相对较少, 全面收回所有权、使用 权和管理权相对容易。

\subsection{3 分步骤、分类别解决保护地内矿业权问题}

对于保护地内违法设立的矿业权一律依法清 理退出。对于依法设置的矿业权, 全面评估各类探 矿、采矿活动对生态环境的影响, 据此分别建立针 对不同类别、不同级别保护地采矿活动正面或负面 清单, 明确少数允许设置的对生态环境影响小的采 矿权, 并推动其绿色转型; 同时, 建立探矿活动负 面清单, 清退一批对生态环境影响较大的探矿权。 尽快制定保护地矿业权退出制度, 明确补偿机制和 补偿标准, 在矿业权退出中, 保障矿业权人的合法 权益, 做好补偿工作, 并设置过渡期, 给利益相关 方相应的准备时间(表 2)。

\section{4 建立健全平衡保护地保护与发展关系的体制} 机制

\subsection{1 完善有利于保护地及周边区域原住居民迁 出的体制机制}

一方面, 着力解决保护地及周边社区教育不充 分问题，提高保护地原住居民主动迁出意愿和能 力。建议在面临大面积贫困的保护地及周边社区推 动十二年制义务教育, 并加强适龄劳动力的职业教 育培训，提升保护地及周边原住居民的生计资本和 能力及年轻一代主动迁出保护地及周边区域的意 愿和能力。另一方面, 调查确定需重点优先开展生
态移民的保护地，并完善生态移民配套政策。全面 调查在保护地内有自然资源所有权、承包经营权的 居民数量和分布，分析原居民对保护地内自然资源 的生计依赖及其生产生活对保护地的生态环境影 响, 结合保护地类型、级别和分区，明确需要优先 实施生态移民的保护地，结合精准扶贫、生态扶贫 逐步有序搬迁。完善失地补偿、产业扶持、教育保 障、居民医疗保险、社会养老保险、文化传承等生 态移民配套政策，确保生态移民搬得出、住得下、 不返迁。

\subsection{2 建立多元共治的保护地治理体系}

要实现保护地更好地治理和相关决策的有效 执行，需改变当前政府绝对主导的治理模式，建立 保护地管理机构、所在地各级政府、社区、公益组 织等多元主体共同参与的治理体系。一方面，需保 障保护地所在地及周边基层政府、社区居民对保护 地管理决策的知情权、参与权、表达权和监督权，培 育当地基层政府、社区对保护地的认同与归属感， 消除矛盾和隔阂; 另一方面，建议将保护地的治理 拓展到保护地外，保护地管理机构有义务参与周边 乡镇的重大决策，并为其可持续发展提供教育、扶 贫、保护地友好型产业发展等方面的支撑; 推动保 护地管理机构参与当地的村民议事会，共同推动社 区的可持续发展。

\subsection{3 建立多元化生态产品价值实现机制, 改善保} 护地内及周边原住居民生计

建立健全的生态产品价值实现机制，是改善保

表2 我国自然保护地矿业权问题的分区分类解决方案

Table 2 Zoning and classification solutions for the problems of mining rights ownership in China's natural protected areas

\begin{tabular}{|c|c|}
\hline 权属类型 & 国家公园、国家级自然保护区 \\
\hline $\begin{array}{l}\text { Types of land } \\
\text { ownership }\end{array}$ & 核心保护区 Core protected area \\
\hline
\end{tabular}

采矿权 推动所有采矿权全部退出 $\quad$ a. 建立采矿活动正面清单, 推动正面清 $\quad$ a. 重点推动绿色矿山建设; b. 建立采矿

Mining rights Promoting to quit all mining rights

探矿权 Exploration rights
保留少数关系到国家战略安全的矿产资源 的探矿权, 推动其余探矿权的全部退出 Reserving the exploration right of a few mineral resources that concern national strategic security and promoting the exit of all exploration rights in the negative list the other exploration rights 中所有探矿权的全面退出
单之外所有采矿权的全面退出; b. 正面 清单内的采矿权, 推动绿色矿山建设 a. Establishing positive lists of mining activities, promoting the exit of all mining rights except the positive list; b. Focusing on building g mining right

活动负面清单, 推动清单中所有采矿权 的退出

a. Focusing on building green mines; $b$. Establishing a negative list of mining activities and promoting the exit of all 建立探矿活动负面清单，推动负面清单 Establishing a negative list of exploration alleviating its ecological environmental activities and promoting the exit of all impact
规范探矿活动, 减轻其生态环境影响 Regulating prospecting activities and ing 
护地内及周边原住居民生计, 协调好保护与发展关 系的有效途径。针对当前我国保护地生态产品价值 实现模式单一的问题, 未来需建立政府补偿、市场交 易、公益捐赠等多元化模式相结合的价值实现机制。

(1)健全保护地生态补偿机制。一是加大对实施 严格保护的国家公园和国家级自然保护区的财政 转移支付和生态补偿力度, 加强因保护利益受损和 丧失发展机会的原住居民的直接补偿。二是拓展补 偿资金来源，探索构建生态受益地区政府、企业投 资购买保护地生态系统服务的机制和途径; 探索生 态债券、生态彩票、生态基金、信托基金、国际资 助、社会捐助等形式作为补偿资金的辅助来源。三 是探索多元化的补偿方式, 因地制宜, 采取项目补 偿、飞地经济、人才培训、就业机会等方式, 改善 原住居民生计。

(2)建立健全原住居民参与的特许经营制度。总 结我国国家公园特许经营体制试点经验，并进一步 在各类保护地深化特许经营制度改革试点，建立符 合各类保护地功能定位、鼓励原住居民和自然资源 所有者参与收益分配的特许经营制度, 并将原住居 民受益情况作为保护地管理成效评估的重要指标。

(3)探索生态产品价值实现的市场化机制。一是 通过建立生态产品交易体系促进生态产品价值实 现。(i)推动保护地自然资源资产产权制度改革, 明 晰各类生态产品的所有权、使用权、收益权, 激活 转让权, 为生态产品产权交易奠定基础(马永欢等, 2020); (ii)制定保护地生态产品价值核算标准, 完善 基于生态产品价值和稀缺性的定价机制; (iii)建立 保护地生态产品交易市场、搭建交易平台，逐步建 立能有效降低交易成本、实现供给双方的平等协 商、公平交易的交易机制; (iv)建立有利于保护地生 态产品价值实现的金融机制, 如建立生态产品产权 抵质押贷款、证券化、远期交易、股权交易等制度。 二是通过发展保护地友好型产业, 促进生态产品价 值实现。根据各类、各级保护地功能定位和保护级 别, 适当、有序发展特色农业、生态旅游、生态康 养等产业，促进产业间的融合，带动一批“绿水青 山”的守护者收获“金山银山”。为了体现保护地高品 质生态产品的真正价值, 建议建立全国统一的针对 各类保护地的产品标识体系, 如国家公园产品标 识、国家级自然保护区产品标识, 遴选全生命周期 内对保护地生态环境影响小, 同时产品质量达到绿
色、有机标准的产品授予标识，使生态产品获得明 显的增值和更好的市场销售前景，将资源环境优势 转化为产品品质优势、价格优势和销量优势, 实现 “绿水青山”向“金山银山”的转化。

\section{参考文献}

Cao W, Huang L, Xiao T, Wu D (2019) Effects of human activities on the ecosystems of China's national nature reserves. Acta Ecologica Sinica, 39, 1338-1350. (in Chinese with English abstract) [曹巍, 黄麟, 肖桐, 吴丹 (2019) 人 类活动对中国国家级自然保护区生态系统的影响. 生态 学报, 39, 1338-1350.]

Cao Y, Yang R, Martin VG (2019) Nature needs half: A new vision for global protected areas. Landscape Architecture Journal, 26(4), 39-44. (in Chinese with English abstract) [曹 越, 杨锐, 万斯·马丁 (2019) 自然需要一半: 全球自然保 护地新愿景. 风景园林, 26(4), 39-44.]

Chen HM, Wang Z (2011) How to treat and deal with the issue of land ownership in nature reserves. Environmental Protection, (4), 27-29. (in Chinese) [陈红梅, 王智 (2011) 怎样看待和处理自然保护区土地权属问题. 环境保护, (4), 27-29.]

Duan W, Ren YM, Feng J, Wen YL (2015) Study on natural resource dependence based on livelihood assets-Example from nature reserve in Hubei Province. Issues in Agricultural Economy, 36(8), 74-82, 112. (in Chinese with English abstract) [段伟，任艳梅，冯冀，温亚利 (2015) 基 于生计资本的农户自然资源依赖研究——以湖北省保护 区为例. 农业经济问题, 36(8), 74-82, 112.]

Gao JX, Xu MJ, Zou CX (2019) Development achievement of natural conservation in 70 years of new China. Chinese Journal of Environmental Management, 11(4), 25-29. (in Chinese with English abstract) [高吉喜, 徐梦佳, 邹长新 (2019) 中国自然保护地70年发展历程与成效. 中国环境 管理, 11(4), 25-29.]

Grazia B, Nigel D, Tilman J, Barbara L, Neema P, Adrián P, Trevor S (2013) Governance of Protected Areas: From Understanding to Action. IUCN, Gland, Switzerland.

Jacobs HM (2014) Conservation Easements in the U.S. and Abroad: Reflections and Views Toward the Future. Lincoln Institute of Land Policy, Lincoln.

Korngold G (2010) Globalizing conservation easements: Private law approaches for international environmental protection. Wisconsin International Law Journal, 28, 585-638.

Lan N, Bao X (2019) Extraterritorial experience and legislative reference of land. Environmental Protection. 47(2), 68-71. (in Chinese) [蓝楠, 包旭 (2019) 自然保护区土地管理的 域外经验及立法借鉴. 环境保护, 47(2), 68-71.]

Li WJ, Ma XR (2009) Local government dominated tourism operational right transfer: Effects on the community’s ability 
to benefit. Journal of Peking University (Philosophy and Social Sciences), 46(5), 146-154. (in Chinese with English abstract) [李文军, 马雪蓉 (2009) 自然保护地旅游经营 权转让中社区获益能力的变化. 北京大学学报(哲学社会 科学版), 46(5), 146-154.]

Liu X, Wu JP, Song WM, Zhang DH, Zhang Y (2011) A comparative study on benefit share mechanism between models of community co-management in China's nature reserve. Forestry Economics, (12), 42-47. (in Chinese with English abstract) [刘霞, 伍建平, 宋维明, 张大红, 张岩 (2011) 我国自然保护区社区共管不同利益分享模式比较 研究. 林业经济, (12), 42-47.]

Liu YR, Xu BG (2019) Study on economic survey and development strategies for local communities of Yinggeling Nature Reserve. Forestry Economics, 41(5), 121-124. (in Chinese with English abstract) [刘奕汝, 许碧果 (2019) 鴙 哥岭自然保护区社区经济状况调查与发展对策研究. 林 业经济, 41(5), 121-124.]

Luo HB, Meng B (2014) Scope and functional regions adjustment and ecological impact on Gongbu Nature Reserve in Tibet. Central South Forest Inventory and Planning, 33(2), 31-33. (in Chinese with English abstract) [罗怀斌, 蒙涁 (2014) 西藏工布自然保护区范围和功能 区调整及生态影响. 中南林业调查规划, 33(2), 31-33.]

Ma B, Cai Z, Zheng J, Wen YL (2019) Conservation, ecotourism, poverty, and income inequality-A case study of nature reserves in Qinling, China. World Development, 115, 236-244.

Ma B, Ding HL, Wen YL (2017) Research on the impact of biodiversity conservation on multidimensional povertyBased on the data of surrounding communities in protected areas in 7 provinces in China. Journal of Agrotechnical Economics, (4), 116-128. (in Chinese) [马奔, 丁慧敏, 温 亚利 (2017) 生物多样性保护对多维贫困的影响研究 一一基于中国7省保护区周边社区数据. 农业技术经济, (4), 116-128.]

Ma Y (2006) The status and existing problems of legislation on nature reserves. Environmental Protection, (21), 42-47. (in Chinese) [马燕 (2006) 我国自然保护区立法现状及存在 的问题. 环境保护, (21), 42-47.]

Ma YH, Wu CG, Cao TY, Tang WH, Kong DK, Ding WW (2020) Basic thinking on the realization mechanism of China's ecological product value. Environmental Protection, 48(Z1), 68-71. (in Chinese) [马永欢, 吴初国, 曹庭语, 汤 文豪, 孔登鬼, 丁问微 (2020) 对我国生态产品价值实现 机制的基本思考. 环境保护, 48(Z1), 68-71.]

Meng B, Zhang JF, Ye H, Chang F, Jiang YG (2019) Current situation and protection enlightenment of the function of fishing spawning grounds in the national nature reserve for the rare and endemic fishes, upper reaches of the Yangtzi River. Resources and Environment in the Yangtzi River Basin, 28, 2772-2785. (in Chinese with English abstract) [孟宝, 张继飞, 叶华, 常飞, 蒋应刚 (2019) 长江上游珍
稀特有鱼类国家级自然保护区鱼类产卵场功能现状分析 及保护启示. 长江流域资源与环境, 28, 2772-2785.]

Ouyang ZY, Wang XK, Miao H, Han NY (2002) Problems of management system of China's nature preservation zones and their solution. Science and Technology Review, (1), 49-52. (in Chinese with English abstract) [欧阳志云, 王效 科, 苗鸿, 韩念勇 (2002) 我国自然保护区管理体制所面 临的问题与对策探讨. 科技导报, (1), 49-52.]

Qian ZD, Guo C, Wu RH, Liang YT, Yang QG, Pan ZP, Pan H, Gao J, Jiang MK (2016) Characteristics and problems in economic investment in nature reserves of China. Journal of Ecology and Rural Environment, 32(1), 35-40. (in Chinese with English abstract) [钱者东, 郭辰, 吴儒华, 梁宇䑣, 杨 泉光, 潘子平, 潘鸿, 高军, 蒋明康 (2016) 中国自然保 护区经济投入特征与问题分析. 生态与农村环境学报, 32(1), 35-40.]

Song ZW (2018) Study on community co-management mechanism of national forest park-A case of Zhuhai National Forest Park in Chishui County. Central South Forest Inventory and Planning, 37(4), 58-61. (in Chinese with English abstract) [宋志伟 (2018) 国家森林公园社区 共管机制研究——赤水竹海国家森林公园为例. 中南 林业调查规划, 37(4), 58-61.]

Sun R, Wang SL, Wu LQ, An H, Qin SY, Liu YJ, Tan WF (2017) How to balance development between nature reserves and community: A case study in Shiwandashan National Nature Reserve, Guangxi. Biodiversity Science, 25, 437-448. (in Chinese with English abstract) [孙润, 王双玲, 吴林巧, 安辉, 覃世赢, 刘有军, 谭伟福 (2017) 保护区 与社区如何协调发展：以广西十万大山国家级自然保护 区为例. 生物多样性, 25, 437-448.]

Tan WF, An H, Tan XN (2016) Why ecological migrants move back to nature reserves: A case study in Shiwandashan National Nature Reserve, Guangxi. Biodiversity Science, 24, 729-732. (in Chinese with English abstract) [谭伟福, 安辉, 谭夏妮 (2016) 为什么自然保护区的生态移民要回迁: 以广西十万大山保护区为例. 生物多样性, 24, 729-732.]

Wang CF (2006) The comparison of the legislation of foreign nature reserves and the perfection of Chinese legislation. Environmental Protection, (21), 73-78. (in Chinese) [王灿 发 (2006) 国外自然保护区立法比较与我国立法的完善. 环境保护, (21), 73-78.]

Wang CH (2017) What do China's nature reserves give to surrounding communities?-Based on survey data of farmers in Shaanxi, Sichuan and Gansu from 1998 to 2014. Management World, (3), 63-75. (in Chinese) [王昌海 (2017) 中国自然保护区给予周边社区了什么?一一基于 1998-2014年陕西、四川和甘肃三省农户调查数据. 管理 世界, (3), 63-75.]

Wang H, Zhao YW, Wen YL (2017) Evaluation on the dependence of rural household on the natural resources based on factor return: A case study on six natural reserves in Yunnan Province. China Population, Resources and 
Environment, 27(12), 146-156. (in Chinese with English abstract) [王会, 赵亚文, 温亚利 (2017) 基于要素报酬的 农户自然资源依赖度评价研究一以云南省六个自然保 护区为例. 中国人口·资源与环境, 27(12), 146-156.]

Wang SF (2010) A research on the pattern of harmonious development of scenic areas and indigenous inhabitants in China. Human Geography, 25(3), 139-143. (in Chinese with English abstract) [王淑芳 (2010) 我国风景名胜区与原居 民和谐发展模式探讨. 人文地理, 25(3), 139-143.]

Wang YW (2019) The management issues and countermeasures of provincial nature reserves in the upper Fenhe River of Shanxi Province. Journal of Green Science and Technology, (20), 29-30. (in Chinese) [王跃文 (2019) 山西汾河上游省级自然保护区管理问题及对策建议. 绿 色科技, (20), 29-30.]

Wang Z, Jiang MK, Qin WH, He ZH, Xu WG (2008) The problem and strategy of protected areas in China. Ecological Environment, (6), 144-146. (in Chinese with English abstract) [王智, 蒋明康, 秦卫华, 贺昭和, 徐网谷 (2008) 我国自然保护区的问题分析与对策. 生态经济, (6), 144-146.]

Worboys GL, Lockwood M, Kothari A, Feary S, Palsford I (2015) Protected Area Governance and Management. Australian National University Press, Canberra.

Xia X, Wang Z, Xu WG, Zhang HN, Zhou DQ, Jiang MK (2016) Problems in construction of management system of nature reserves in China and countermeasures. Journal of Ecology and Rural Environment, 32(1), 30-34. (in Chinese with English abstract) [夏欣, 王智, 徐网谷, 张吴楠, 周大 庆, 蒋明康 (2016) 中国自然保护区管理机构建设面临 的问题与对策探讨. 生态与农村环境学报, 32(1), 30-34.]

Xiang YG, Chen XL, Wang ZY, Tan ZY, Yang BX (2019) Discussion on conservation management of nature reserve in Xiangxi Autonomous Prefecture. Forestry Construction, (5), 25-29. (in Chinese with English abstract) [向玉国, 陈衔凌, 王宗永, 谭子幼, 杨必祥 (2019) 湖南湘西自治州自然保 护区保护管理探讨. 林业建设, (5), 25-29.]

Xiao JH, Zhou XF (2009) The collective land management and community co-management contract in nature reserves. Seeker, (2), 5-7. (in Chinese) [肖建华, 周训芳 (2009) 自 然保护区集体土地管理与社区共管契约. 求索, (2), 5-7.]

Xu WG, Gao J, Xia X, Zhou DQ, Li ZL, Jiang MK (2016) Distribution of community residents in nature reserves and its impacts on the reserves in China. Journal of Ecology and Rural Environment, 32, 19-23. (in Chinese with English abstract) [徐网谷, 高军, 夏欣, 周大庆, 李中林, 蒋明康
(2016) 中国自然保护区社区居民分布现状及其影响. 生 态与农村环境学报, 32, 19-23.]

Xu WH, Xiao Y, Zhang JJ, Yang W, Zhang L, Hull V, Wang Z, Zheng H, Polasky S, Jiang L, Xiao Y, Shi XW, Rao EM, Lu F, Wang XK, Daily G, Ouyang ZY (2017) Strengthening protected areas for biodiversity and ecosystem services in China. Proceedings of the National Academy of Sciences, USA, 114, 1601-1606.

Zhang B, Li GJ (2017) Problems and countermeasures of mineral right withdrawal in nature reserve. China Mining Magazine, 26(4), 1-3. (in Chinese with English abstract) [张 博, 利广杰 (2017) 自然保护区内矿业权退出面临问题 及对策. 中国矿业, 26(4), 1-3.]

Zhang X (2012) Franchising or monopoly: One of perspectives on tourism management in our country's world heritage sites. Tourism Tribune, 27(5), 6-8. (in Chinese with English abstract) [张晓 (2012) 特许经营还是垄断经营: 我国世 界遗产地旅游经营透视之一。旅游学刊, 27(5), 6-8.]

Zhang YX, Hu YX, Zhang B, Li YX, Zhang XY, Yi X (2020) Conflict between nature reserves and surrounding communities in China: An empirical study based on a social and ecological system framework. Global Ecology and Conservation, 21, e00804.

Zhao G, Lü B, Zhang L (2013) Research on the business model of scenic area under the participation of residents-A case study of Three Gorges Scenic Area of Yangtzi River. Chinese Journal of Agricultural Resources and Regional Planning, 34(6), 58-64. (in Chinese with English abstract) [赵刚, 吕斌, 张俐 (2013) 基于村民参与的风景名胜区 经营模式研究——长江三峡风景名胜区为例. 中国农 业资源与区划, 34(6), 58-64.]

Zhou DQ, Gao J, Qian ZD, Zhang HN, Xu WG, Jiang MK (2016) Evaluation of in-situ conservation of vertebrates in China. Journal of Ecology and Rural Environment, 32, 7-12. (in Chinese with English abstract) [周大庆, 高军, 钱者东, 张昊楠, 徐网谷, 蒋明康 (2016) 中国脊椎动物就地保护 状况评估. 生态与农村环境学报, 32, 7-12.]

Zhou JH, Wen YL (2006) The current condition and development trend of land ownership management in nature reserves in China. Environmental Protection, (21), 60-63. (in Chinese) [周建华, 温亚利 (2006) 中国自然保护区土 地权属管理现状及发展趋势. 环境保护, (21), 60-63.]

(责任编委: 徐卫华 责任编辑: 黄祥忠) 